\title{
Enhancement of Lignin Biopolymer Isolation from Hybrid Poplar by Organosolv Pretreatments
}

\author{
Miao Wu, ${ }^{1}$ Jinhui Pang, ${ }^{1}$ Xueming Zhang, ${ }^{1}$ and Runcang Sun ${ }^{1,2}$ \\ ${ }^{1}$ Beijing Key Laboratory of Lignocellulosic Chemistry, Beijing Forestry University, Beijing 100083, China \\ ${ }^{2}$ State Key Laboratory of Pulp and Paper Engineering, South China University of Technology, Guangzhou 510640, China \\ Correspondence should be addressed to Xueming Zhang; xm_zhang@bjfu.edu.cn
}

Received 30 April 2014; Revised 15 August 2014; Accepted 15 August 2014; Published 28 August 2014

Academic Editor: Geoffrey R. Mitchell

Copyright (c) 2014 Miao Wu et al. This is an open access article distributed under the Creative Commons Attribution License, which permits unrestricted use, distribution, and reproduction in any medium, provided the original work is properly cited.

\begin{abstract}
Lignocellulosic biomass is an abundant renewable resource that has the potential to displace petroleum in the production of biomaterials and biofuels. In the present study, the fractionation of different lignin biopolymers from hybrid poplar based on organosolv pretreatments using $80 \%$ aqueous methanol, ethanol, 1-propanol, and 1-butanol at $220^{\circ} \mathrm{C}$ for 30 min was investigated. The isolated lignin fractions were characterized by Fourier transform infrared spectroscopy (FT-IR), high-performance anion exchange chromatography (HPAEC), 2D nuclear magnetic resonance (2D NMR), and thermogravimetric analysis (TGA). The results showed that the lignin fraction obtained with aqueous ethanol (EOL) possessed the highest yield and the strongest thermal stability compared with other lignin fractions. In addition, other lignin fractions were almost absent of neutral sugars (1.16-1.46\%) though lignin preparation extracted with 1-butanol (BOL) was incongruent (7.53\%). 2D HSQC spectra analysis revealed that the four lignin fractions mainly consisted of $\beta-O-4^{\prime}$ linkages combined with small amounts of $\beta-\beta^{\prime}$ and $\beta-5^{\prime}$ linkages. Furthermore, substitution of $\mathrm{C}_{\alpha}$ in $\beta-O-4^{\prime}$ substructures had occurred due to the effects of dissolvent during the autocatalyzed alcohol organosolv pretreatments. Therefore, aqueous ethanol was found to be the most promising alcoholic organic solvent compared with other alcohols to be used in noncatalyzed processes for the pretreatment of lignocellulosic biomass in biorefinery.
\end{abstract}

\section{Introduction}

With an increasing societal focus on environmental and economic sustainability, renewable energy and materials from nonfood bioresources, especially wood, are drawing increasing attention of governments, industries, and consumers as well as research institutes [1]. Furthermore, the demand for petroleum-derived fuels is not slowing down but instead increasing substantially over the past few decades [2]. Therefore, in the current situations, environmentally friendly biomass resources such as lignocellulosic materials (LCM) should be utilized effectively as an alternative to fossil resources [3]. However, LCM are composed of carbohydrates (cellulose and hemicelluloses), lignin, and small amounts of extractives and minerals in a three-dimensional, complex, and rigid cell-wall structure which makes them recalcitrant to biological and chemical degradation and difficult to be separated into readily utilizable components $[4,5]$. Thus the biomass refinery approach based on the selective separation and specific utilization of the major components in LCM (cellulose, hemicelluloses, and lignin) has recently become a focus of research [6].

In biorefinery, the production of cellulosic ethanol mainly involves three steps: pretreatment, enzymatic hydrolysis, and fermentation. In this bioconversion route, lignin content had significant impact on the cellulose hydrolysis rate [7]. Lignin, the second most abundant renewable biopolymer on the Earth, exists in all woody plants and plays a vital role in plant growth and development by improving water conduction through xylem tracheary elements and enhancing the strength of fibrous tissues [8]. This complex polymer is mainly composed of substituted phenylpropane units, which are linked together to form a polymer lacking regularity, crystallinity, or optical activity. Therefore, it is a significant factor in the manufacture of products derived from plants. To overcome this recalcitrant property, pretreatment is likely the most crucial step as it has a large impact on the lignin separation efficiency and carbohydrates conversion of the overall 
process [8]. In detail, this stage is required to alter the structure of LCM to make cellulose more accessible to the enzymes that convert the carbohydrate polymers into fermentable sugars as represented in Figure 1 [7]. Therefore, the focus of this study was on the predissolution of lignin biopolymer with organosolv pretreatment, which would affect downstream processing performance.

Nowadays various pretreatment methods including physical, chemical, biological, and thermal approaches have been developed and among them the organosolv pretreatment has great potential to be exploited. Initially, organosolv process was only developed for processing wood into pulp for paper manufacturing $[9,10]$, and afterwards it was demonstrated that the lignin obtained was barely changed compared to its native form. At present, it has been a promising pretreatment for efficient fractionation of LCM on account of the following advantages over other pretreatment methods: (a) organic solvents can be easily recycled by distillation because of their relatively low boiling points; (b) the acquired lignin after pretreatment is of high quality so that it can be applied in the field of composites or biodegradable polymers [11], such as phenolic resins [12] and adhesives [13]; (c) the pretreatment considers the full availability of all the biomass components, which makes it feasible for biorefining of LCM [14].

Organosolv delignification has been performed with and without catalysts (namely, autocatalytic and catalytic) [15-17]. Traditionally, it was usually favored by the addition of catalysts (e.g., $\mathrm{H}_{2} \mathrm{SO}_{4}$ ) [15]. However, the presence of acid catalyst caused equipment corrosion and also involved additional steps for recovery and recycling, which had some impact on the economies of the global process, as well as hindering further upgrading of lignin for high valued-added utilization. In addition, the presence of organic solvents helps to dissolve lignin fraction, which was beneficial for the transition of carbohydrates in downstream treatments. Furthermore, autocatalyzed organosolv lignin tended to have high purity $(>70 \%)$ and be essentially free of sulphur and ash [18]. Hence the organosolv pretreatment process without catalysts should be further developed. On the other hand, many solvents have been evaluated in the organosolv process (e.g., methanol, ethanol, acetic acid, and acetone). Among them, ethanol has been widely studied as a renewable and green solvent because it can be easily recycled due to its volatility [19] and can scarcely produce environmental pollution. In addition, ethanol-based organosolv pretreatment has been studied for different types of LCM including hardwoods (e.g., willow [20], poplar [21]), softwoods (e.g., lodgepole pine [22, 23]), and herbaceous crops (e.g., miscanthus $[5,17])$. Other alcohols such as methanol and 1, 4-butanediol have also been explored in previous literature [24-26]. So far, most studies have just investigated the effect of single alcohol on the lignocellulosic pretreatment. However, research on comprehensive comparisons of different alcohols applied in biomass pretreatment is extremely limited. As a consequence, the objective of the present study was to discover and compare the effect of organosolv pretreatments using different kinds of alcohols with low boiling points as treatment solvents, which was totally different compared with the previous research using ammonia hydrothermal system [27]. For

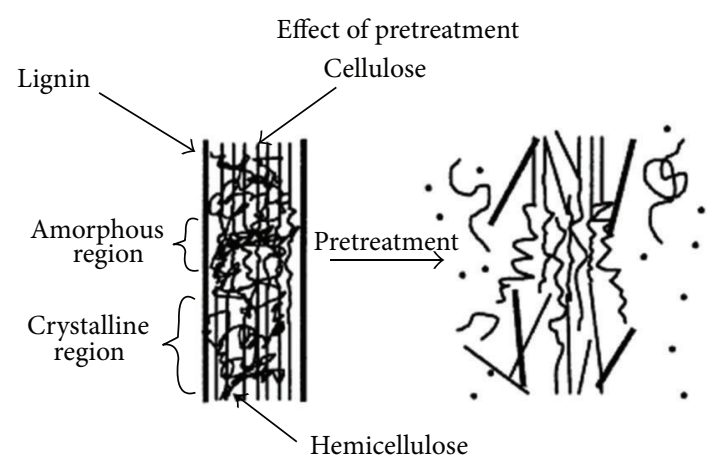

FIGURE 1: Schematic of goals of pretreatment on LCM (quoted from [7]).

this purpose, the hybrid poplar wood powder was treated with methanol, ethanol, 1-propanol, and 1-butanol and the obtained lignin samples were characterized with spectroscopic and chromatographic techniques including Fourier transform infrared spectroscopy (FT-IR), high-performance anion exchange chromatography (HPAEC), 2D heteronuclear single quantum coherence nuclear magnetic resonance (2D-HSQC NMR), and thermogravimetric analysis (TGA).

\section{Experimental}

2.1. Materials. Hybrid poplar (Populus bolleana $\times$ Populus tomentosa Carr.), 7 years old, was obtained from the experimental farm of Beijing Forestry University. The collected wood samples were dried at $50^{\circ} \mathrm{C}$ for $24 \mathrm{~h}$ and then milled with a cutting mill to pass through a 40 -mesh sieve. The milled wood was extracted with $90 \%(\mathrm{v} / \mathrm{v})$ acetone/water in a Soxhlet apparatus for $24 \mathrm{~h}$, and the extractive-free wood was dried under vacuum for several days. Then the dried wood was ground for $48 \mathrm{~h}$ in a 1-gallon porcelain jar containing 9 porcelain balls to get the final wood powder samples for further experiment. The hybrid poplar wood was mainly composed of $32.14 \%$ cellulose, $16.55 \%$ hemicelluloses, $22.38 \%$ lignin, and $0.24 \%$ ash according to the NREL standard method determination [28]. All chemicals used were of analytical grade.

2.2. Separation of Lignin Fractions. Figure 2 shows the separation procedures of lignin fractions extracted with organosolv pretreatment systems from hybrid poplar wood. The ballmilled wood powder $(10 \mathrm{~g})$ was treated with $200 \mathrm{~mL}$ of $80 \%$ aqueous methanol (alcohol/water: 80/20, v/v) without catalysts at $220^{\circ} \mathrm{C}$ for $30 \mathrm{~min}$ in a $1.0 \mathrm{~L}$ Parr reactor (Parr Instrument Company, USA). Then, the treated wood was filtered and washed with the corresponding alcoholic solution. The filtrate was evaporated under reduced pressure to remove the solvents and the residue was poured into water and $\mathrm{pH}$ was adjusted to $1.5-2$ with $1 \mathrm{M} \mathrm{HCl}$ to precipitate the dissolved lignin. Other lignin samples were extracted with aqueous ethanol, 1-propanol, and 1-butanol from raw ball-milled wood sample under the same separation procedures as described above. These lignin fractions, obtained by extraction with 


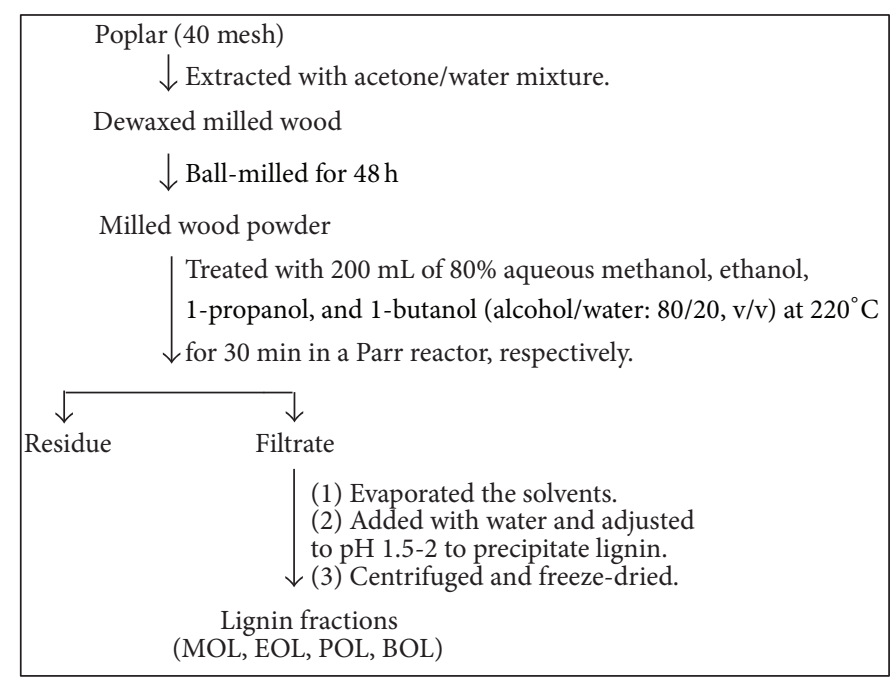

FIGURE 2: Scheme for separation of the alcohol lignin fractions from hybrid poplar.

the mixtures with water of aqueous methanol, ethanol, 1-propanol, and 1-butanol, were labeled as MOL, EOL, POL, and BOL, respectively.

\subsection{Structural Characterization of Lignin Fractions}

2.3.1. Sugar Analysis. The monosaccharide composition of the lignin fractions was determined by HPAEC-PAD as reported previously [2].

2.3.2. FT-IR Spectra. FT-IR spectra of lignin samples were conducted on a Thermo Scientific Nicolet iN10 FT-IR Microscope (Thermo Nicolet Corporation, Madison, WI) equipped with a liquid nitrogen cooled MCT detector. Each spectrum was recorded in the range from 4000 to $650 \mathrm{~cm}^{-1}$ at $4 \mathrm{~cm}^{-1}$ resolution and 128 scans per sample.

2.3.3. Nuclear Magnetic Resonance Spectra. 2D HSQC NMR spectra were acquired on a Bruker AVIII NMR $400 \mathrm{MHz}$ spectrometer in the HSQC GE experiment mode with $40 \mathrm{mg}$ of lignin samples dissolved in $0.5 \mathrm{~mL}$ dimethylsulfoxide- $d_{6}$ (DMSO- $d_{6}$ ). The spectral widths for the HSQC (semiquantitative mode) were 5000 and $20000 \mathrm{~Hz}$ for the ${ }^{1} \mathrm{H}$ - and ${ }^{13} \mathrm{C}$ dimensions, respectively. The number of collected complex points was 1024 for the $1 \mathrm{H}$-dimension with a recycle delay $\left(d_{1}\right)$ of $5 \mathrm{~s}$. The number of transients for the HSQC spectra was 128 , and 256 time increments were recorded in the ${ }^{13} \mathrm{C}$ dimension. The ${ }^{1} J_{\mathrm{C}-\mathrm{H}}$ used was $146 \mathrm{~Hz}$. Prior to Fourier transformation, the data matrixes were zero filled up to 1024 points in the ${ }^{13} \mathrm{C}$-dimension. Data processing was performed using standard Bruker Topspin-NMR software. The central solvent (DMSO- $d_{6}$ ) peak was used as an internal chemical shift reference point $\left(\delta_{\mathrm{C}} 39.5 ; \delta_{\mathrm{H}} 2.49 \mathrm{ppm}\right)$.

A semiquantitative analysis of the HSQC cross-signal intensities was also performed and the procedures were in accordance with those previously reported in the literature [27].
TABLE 1: Yields (\% Klason lignin) and neutral sugar compositions (\% dry weight, w/w) of the alcohol lignin fractions extracted from hybrid poplar.

\begin{tabular}{lcccc}
\hline & \multicolumn{4}{c}{ Lignin preparations $^{\mathrm{a}}$} \\
& MOL & EOL & POL & BOL \\
\hline Yield ${ }^{\mathrm{b}}$ (\%) & 45.5 & 72.1 & 51.4 & 5.7 \\
Total sugars (\%) & 1.16 & 1.41 & 1.46 & 7.53 \\
Arabinose & 0.07 & 0.06 & ND $^{\mathrm{c}}$ & 0.70 \\
Galactose & 0.10 & 0.10 & 0.05 & 0.43 \\
Glucose & 0.22 & 0.20 & 0.11 & 2.45 \\
Xylose & 0.77 & 1.05 & 1.30 & 3.28 \\
Mannose & ND & ND & ND & 0.45 \\
Rhamnose & ND & ND & ND & 0.09 \\
Glucuronic acid & ND & ND & ND & 0.13 \\
\hline
\end{tabular}

${ }^{a} \mathrm{MOL}, \mathrm{EOL}, \mathrm{POL}$, and BOL represent lignin fractions extracted with aqueous methanol, ethanol, 1-propanol, and 1-butanol, respectively.

${ }^{b}$ Yield means the percentage of the extracted lignin to the initial wood Klason lignin content.

${ }^{\mathrm{c}} \mathrm{ND}$ : not detected.

2.3.4. Thermogravimetric Analysis (TGA). Thermal analysis of the lignin fractions was performed using thermogravimetric analysis (TGA) on a simultaneous thermal analyzer (NetzschSTA-449F3).

\section{Results and Discussion}

3.1. Yields and Sugar Analysis of Lignin Fractions. By comparing the yields of the four lignin preparations as shown in Table 1, EOL obviously owned the highest yield followed by MOL and POL with the similar yields, whereas BOL showed the prominently lowest yield. It has been shown that fractionation of lignin (delignification) based on organosolv pretreatment is a combination of lignin degradation and dissolution of degraded lignin fragments; the properties of organic solvents and their concentration can have a dramatic impact on 
the delignification $[15,16]$. Generally, the lignin polymer was depolymerized by acid-catalyzed cleavage of $\alpha$ - and $\beta$-ether linkages in lignin due to the presence of acetic acid derived from the hydrolysis of the acetyl group in hemicelluloses at elevated temperature. Therefore, the relatively higher yield of EOL was mainly attributed to good lignin degradation, which depended on the excellent solvent nucleophilic property, and an equally good solubility in ethanol-water mixture. On contrary, relatively poor miscibility of 1-butanol with water resulted in the low lignin yield.

The composition and content of neutral sugars in the four isolated lignin fractions are also given in Table 1. In comparison with the neutral sugars $(7.53 \%)$ in BOL, the lignin preparations MOL, EOL, and POL only contained a small quantity of associated polysaccharides, ranging from 1.16 to $1.46 \%$. In addition, it was also found that the content of neutral sugars in the obtained lignin increased with the increase of the alkyl chain length of the alcohols. Xylose (0.77$3.28 \%)$ and glucose $(0.11-2.45 \%)$ were observed as the major sugar contaminate, which originated from xylan and cellulose in the poplar. Minor amounts of arabinose and galactose were also detected. Regarding the yield and purity, ethanol organosolv pretreatment was an appropriate method as compared with other organic solvents to fractionate lignin from lignocellulosic biomass.

3.2. FT-IR Spectra. Figure 3 illustrates the FT-IR spectra of the four lignin fractions. Peaks were identified by comparing their wave numbers with literature data [29]. The absorption at $3498 \mathrm{~cm}^{-1}$ was assigned to $\mathrm{O}-\mathrm{H}$ stretching vibration, which mainly comes from alcohol hydroxyl and phenolic hydroxyl groups in lignin fractions and residual sugars, and the peaks at 2939 and $2842 \mathrm{~cm}^{-1}$ were attributed to $\mathrm{C}-\mathrm{H}$ stretching vibration in $\mathrm{CH}_{2}$ and $\mathrm{CH}_{3}$ groups, respectively. The band at $1711 \mathrm{~cm}^{-1}$ was due to $\mathrm{C}=\mathrm{O}$ stretching vibrations of unconjugated ketones, carbonyls, or ester groups or conjugated aldehydes and carboxylic acids. The typical lignin peaks at 1594,1512 , and $1420 \mathrm{~cm}^{-1}$, corresponding to aromatic skeletal vibrations and the absorption at $1459 \mathrm{~cm}^{-1}$, derived from methoxyl $\mathrm{C}-\mathrm{H}$ deformations and bending of lignin, were obviously observed in the spectra. Condensed S and $\mathrm{G}$ rings exhibited absorption at $1326 \mathrm{~cm}^{-1}$ and the absorption of 1272 and $1029 \mathrm{~cm}^{-1}$ was associated with $\mathrm{G}$ units, whereas aromatic $\mathrm{C}-\mathrm{H}$ in-plane deformation of S units appeared at $1114 \mathrm{~cm}^{-1}$ [30]. In previous studies, it has been proved that G-type lignin showed a maximum band at $1140 \mathrm{~cm}^{-1}$, while a few percent of $\mathrm{S}$ units in lignin was enough to change the maximum peak from $1140 \mathrm{~cm}^{-1}$ to a wave number below $1128 \mathrm{~cm}^{-1}$ [31]. Furthermore, the other bands at 1216 and $831 \mathrm{~cm}^{-1}$ were ascribed to the $\mathrm{C}-\mathrm{C}, \mathrm{C}-\mathrm{O}$, and $\mathrm{C}=\mathrm{O}$ stretching $(\mathrm{G}$ condensed $>\mathrm{G}$ e therified) [29] and $\mathrm{C}-\mathrm{H}$ out of plane deformation of $\mathrm{G}$ and $\mathrm{S}$ units, respectively. As can be seen from the spectra, the peaks and the absorption intensity of the four samples were rather similar, indicating an analogous and initial structure of the lignin samples. However, the intensity of the band at $1216 \mathrm{~cm}^{-1}$ was significantly different from BOL, which meant that BOL occupied more condensed $\mathrm{G}$ units than other samples.

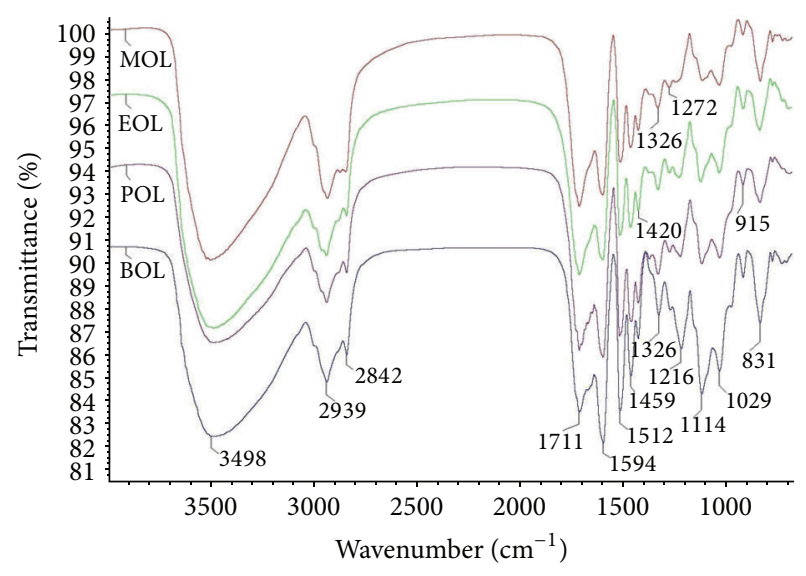

FIGURE 3: FT-IR spectra of the lignin preparations from hybrid poplar.

3.3. Heteronuclear Single Quantum Correlation (HSQC) Spectra. To further investigate the structural characteristics and changes of the obtained lignin fractions, all samples were characterized by 2D HSQC NMR analysis. The HSQC NMR spectra of the four lignin fractions are shown in Figures 4 and 5, including the side chain $\left(\delta_{\mathrm{C}} / \delta_{\mathrm{H}} 50-90 / 2.5-6.0 \mathrm{ppm}\right)$ region and the aromatic $\left(\delta_{\mathrm{C}} / \delta_{\mathrm{H}} 100-155 / 5.5-8.5 \mathrm{ppm}\right)$ region. The main cross-signals assigned based on the recent literature $[18,32-34]$ are listed in Table 2, and the main substructures presented are depicted in Figure 6.

Various interunit linkages present in lignin were observed in the side chain region as shown in Figure 4. The phenomenon detected was the same as previously found that $\beta$ $O-4^{\prime}$ substructures (A) were shown as the most prominent signals, of which $\mathrm{C}_{\alpha}$ and $\mathrm{C}_{\gamma}$ positions were observed at $\delta_{\mathrm{C}} / \delta_{\mathrm{H}}$ 71.6/4.82 and 59.9/3.40-3.68 ppm. Simultaneously, $\mathrm{C}_{\beta}$ positions of $\beta-O-4^{\prime}$ linkages were identified at $\delta_{\mathrm{C}} / \delta_{\mathrm{H}} 84.0 / 4.28$ and $85.8 / 4.12 \mathrm{ppm}$ in $\mathrm{G}$ and $\mathrm{S}$ type lignins, respectively. In addition, the signals for $\mathrm{C}_{\alpha}-\mathrm{H}_{\alpha}, \mathrm{C}_{\beta}-\mathrm{H}_{\beta}$, and $\mathrm{C}_{\gamma}-\mathrm{H}_{\gamma}$ in resinol substructures $\left(\beta-\beta^{\prime}, \mathrm{B}\right)$ were determined by $84.8 / 4.62$, $53.5 / 3.07$, and $71.0 / 3.80$ and $4.15 \mathrm{ppm}$. The correlations of $\mathrm{C}_{\alpha}-\mathrm{H}_{\alpha}, \mathrm{C}_{\beta}-\mathrm{H}_{\beta}$, and $\mathrm{C}_{\gamma}-\mathrm{H}_{\gamma}$ from phenylcoumaran substructures $\left(\beta-5^{\prime} / \alpha-O-4^{\prime}, \mathrm{C}\right)$ were also present at $\delta_{\mathrm{C}} / \delta_{\mathrm{H}} 86.8 / 5.45$, $53.0 / 3.48$, and $62.5 / 3.70 \mathrm{ppm}$. Apart from the above basic linkages, minor amounts of cinnamyl alcohol end-groups (F) were also detected in all lignin samples, as shown by the $\mathrm{C}_{\gamma}-\mathrm{H}_{\gamma}$ cross-peak at 61.2/4.08 [35]. According to the reaction mechanism discussed previously, the solvolytic splitting of $\alpha$ aryl ether in lignin resulted in the formation of a benzylic carbocation, which would react with different alcohols in an acidic medium. Therefore, the extraction solvent could serve as a nucleophile and preferably lead to substitution at the $\alpha$-carbon of $\beta$-O- $4^{\prime}$ substructures [36]. This was confirmed by the appearance of signals at $\delta_{\mathrm{C}} / \delta_{\mathrm{H}} 80.0 / 4.50$ in the four spectra of Figure 4, which represented $\alpha$-methoxylated, ethoxylated, propoxyed, and butoxyed $\beta-O-4^{\prime}\left(\mathrm{A}^{\prime}\right)$, respectively. Furthermore, methyl in $\mathrm{A}^{\prime}$ of MOL was observed at $\delta_{\mathrm{C}} / \delta_{\mathrm{H}} 56.5 / 3.18$ and methylene in $\mathrm{A}^{\prime}$ of EOL, POL, and BOL was also separately revealed by $\delta_{\mathrm{C}} / \delta_{\mathrm{H}} 64.0 / 3.35,70.0 / 3.22$, 


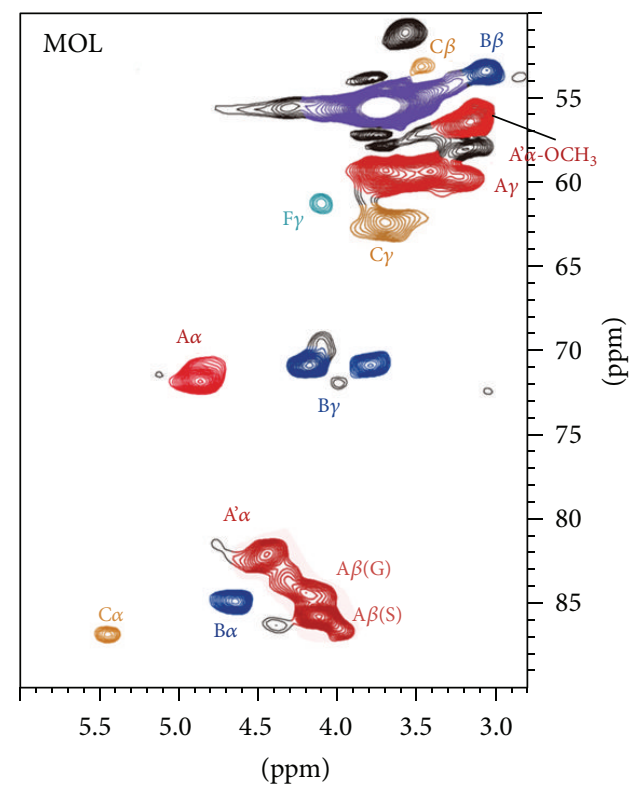

(a)

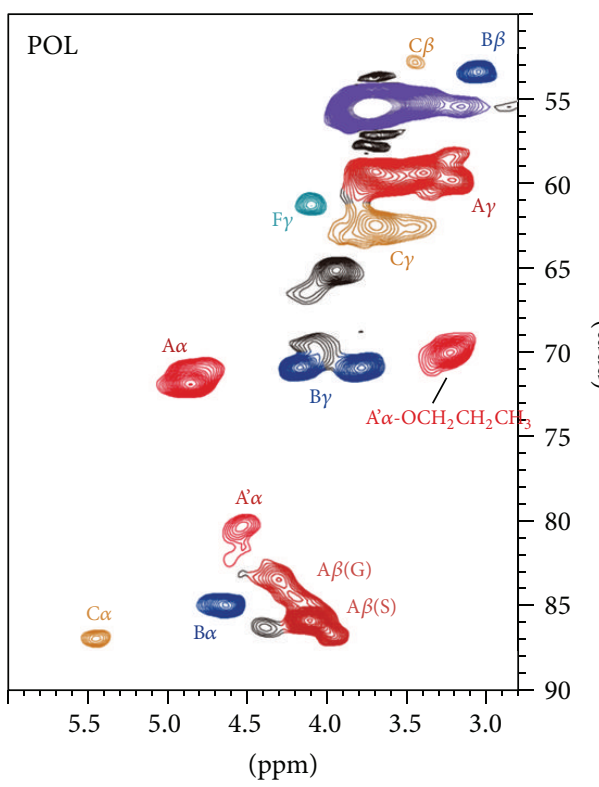

(c)

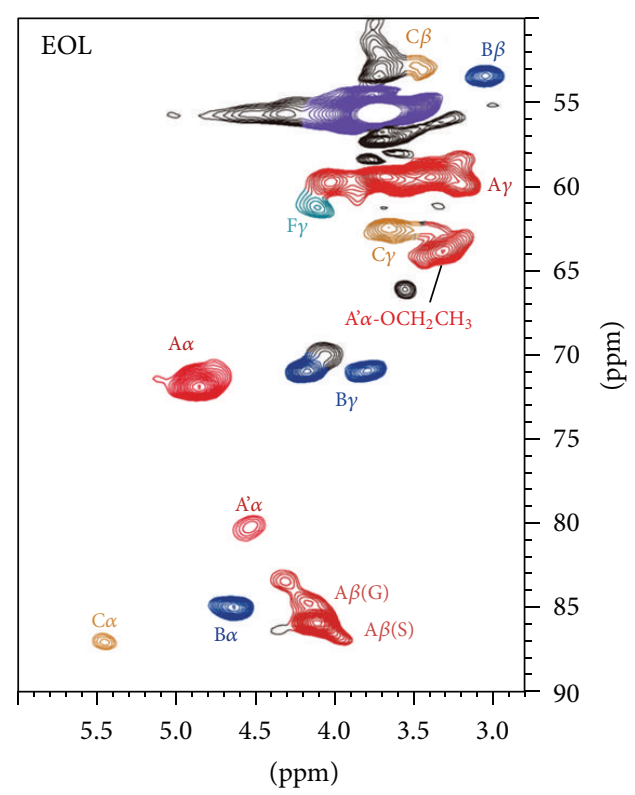

(b)

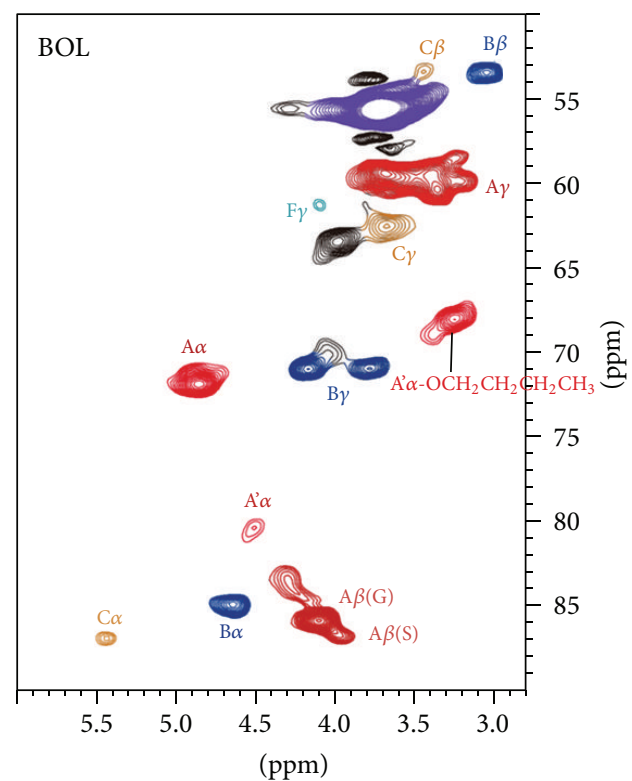

(d)

FIgURE 4: Side chain $\left(\delta_{\mathrm{C}} / \delta_{\mathrm{H}} 45-90 / 2.6-6.0\right)$ regions in the 2D HSQC NMR spectra of the lignin fractions.

and 68.0/3.28, respectively $[18,24,25]$. The clear and strong signals at $\delta_{\mathrm{C}} / \delta_{\mathrm{H}} 65.2 / 3.92$ in POL and $\delta_{\mathrm{C}} / \delta_{\mathrm{H}} 63.2 / 4.02$ in BOL were assigned to the residual propanol and butanol, because they would produce strong signals in NMR spectra even if the residual alcohols were scarce.

In the aromatic regions, the $\mathrm{C}_{2,6}-\mathrm{H}_{2,6}$ correlation of S-type lignin units showed a prominent signal at $\delta_{\mathrm{C}} / \delta_{\mathrm{H}}$ $103.8 / 6.62 \mathrm{ppm}$, whereas the corresponding signal of $\mathrm{C}_{\alpha^{-}}$ oxidized $\mathrm{S}$ units occurred at $\delta_{\mathrm{C}} / \delta_{\mathrm{H}} 106.5 / 7.18$. Moreover, $\mathrm{G}$ units give correlations for $\mathrm{C}_{2}-\mathrm{H}_{2}, \mathrm{C}_{5}-\mathrm{H}_{5}$, and $\mathrm{C}_{6}-\mathrm{H}_{6}$ at $\delta_{\mathrm{C}} / \delta_{\mathrm{H}} 111.0 / 6.95,115.0 / 6.72$, and $118.8 / 6.72$, respectively. As seen in Figure 5, both condensed $\mathrm{G}$ and $\mathrm{S}$ units could be observed. It was noted that BOL was found to obtain a maximum of condensed $G$ units as shown in contours at $\mathrm{C}_{6}$ position of $\mathrm{G}$, which was in accordance with the result of FT-IR spectra. In addition, two obvious signals at $\delta_{\mathrm{C}} / \delta_{\mathrm{H}}$ $109.5 / 7.10$ and $126.0 / 6.98 \mathrm{ppm}$ were attributed to the $\mathrm{C}_{2}-\mathrm{H}_{2}$ and $\mathrm{C}_{\alpha / \beta}-\mathrm{H}_{\alpha / \beta}$ of the stilbenes units. In this region, other cross-peaks also existed in remarkable amount including $p$ hydroxybenzoate substructures (PB) [37] and cinnamyl alcohol end-groups ( $\mathrm{F}$ ) as revealed by $\mathrm{C}_{2,6}-\mathrm{H}_{2,6}$ and $\mathrm{C}_{\alpha / \beta}-\mathrm{H}_{\alpha / \beta}$ at $\delta_{\mathrm{C}} / \delta_{\mathrm{H}} 129.8 / 7.50$ and $122.0 / 7.05$, respectively.

To evaluate the relative ratio of the major lignin side chains, the calculation was conducted according to the literature by integration of the signals on interunit linkages $[33,38]$ and the results are listed in Table 3 . Obviously, the $\beta-O-4^{\prime}$ aryl 


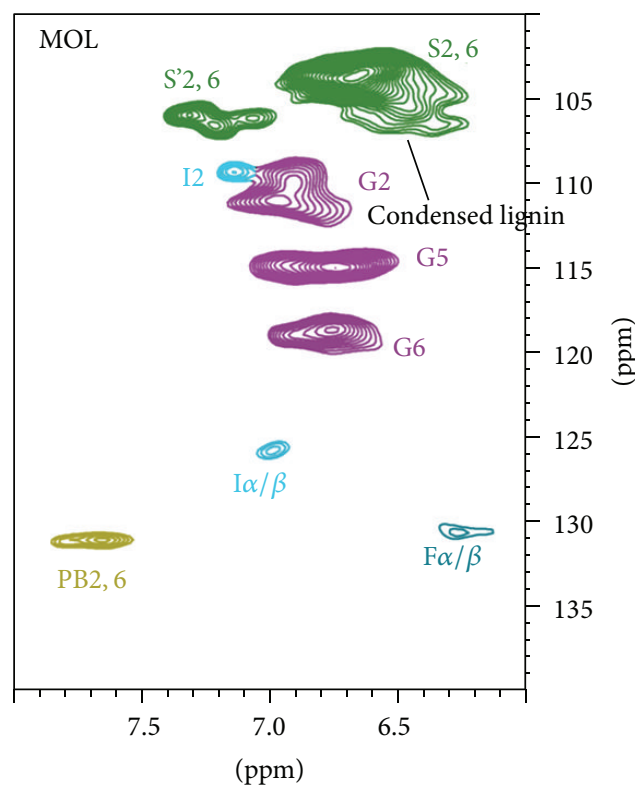

(a)

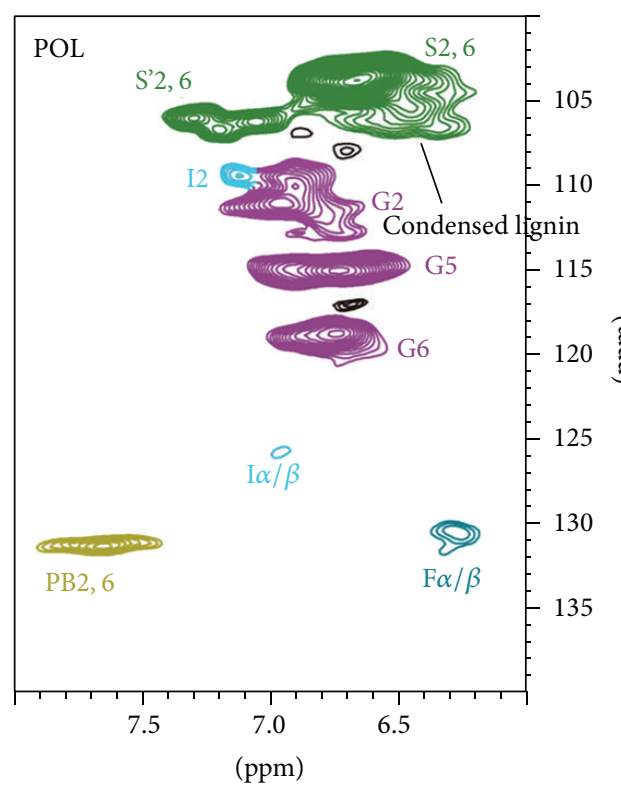

(c)

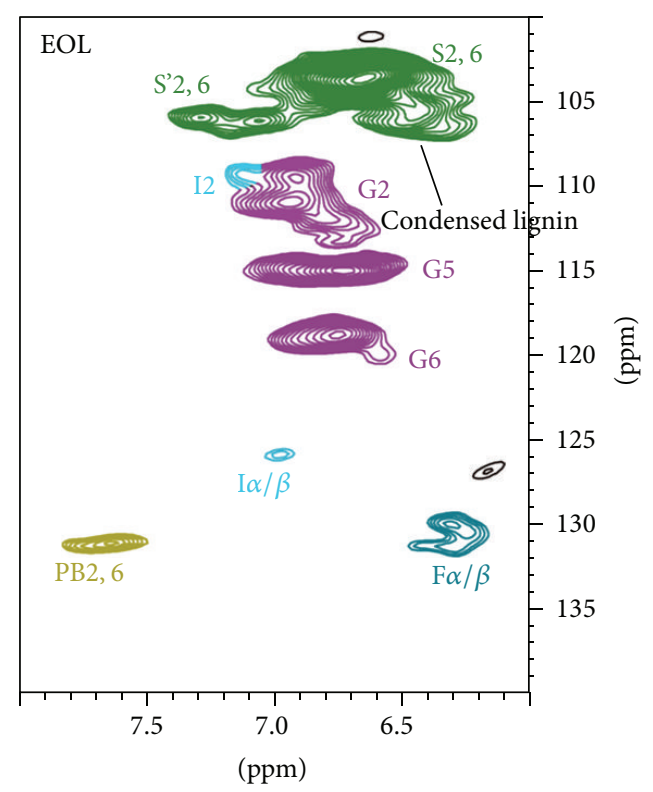

(b)

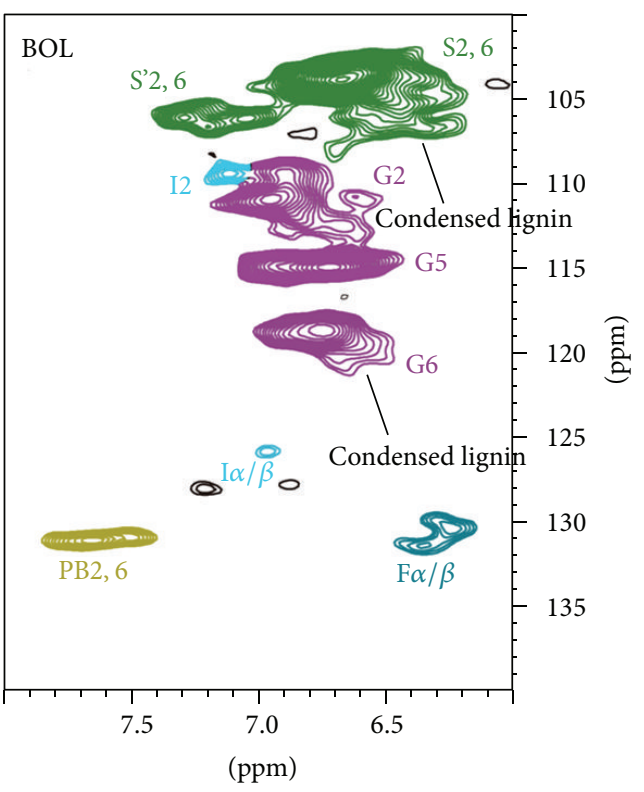

(d)

FIGURE 5: Aromatic $\left(\delta_{\mathrm{C}} / \delta_{\mathrm{H}} 90-150 / 6.0-8.0\right)$ regions in the 2D HSQC NMR spectra of the lignin fractions.

ether linkages were the main side chains interunit linkages, accounting for $60.7-70.6 \%$ of all detectable side chains, followed by $\beta-\beta^{\prime}$ resinol $(24.0-31.7 \%)$ and $\beta-5^{\prime}$ phenylcoumaran (5.0-7.6\%) linkages. Moreover, the ratio of S/G indicated that $S$ units occupied the dominant part in the lignin isolated under the conditions given, followed by significant amounts of $\mathrm{G}$ units.

3.4. Thermogravimetric Analysis (TGA). The thermal properties of lignin are of vital importance for its application in thermochemical conversion into energy and chemicals, for example, thermolysis [39], which is related to specific structures of lignin. Therefore, the thermal stability has been investigated by the thermogravimetric analysis. The relationship between the weight losses of lignin samples and temperature is revealed by TG curves in Figure 7, while Figure 8 shows DTG curves.

As can be seen from Figure 7, the decomposition processes of the lignin samples can be divided into several stages. During the initial stage, the first peak appearing in DTG curve below $100^{\circ} \mathrm{C}$ was ascribed to the moisture retained in the lignin. In the temperature range of 100 to $200^{\circ} \mathrm{C}$, obvious weight loss was observed especially from that of BOL, which could be attributed to the dehydration of lignin biopolymer [40]. Subsequently, a rapid degradation rate of weight 
TABLE 2: Assignments of ${ }^{13} \mathrm{C}-{ }^{1} \mathrm{H}$ correlation signals in the 2D HSQC spectra of the alcohol lignin fractions from hybrid poplar.

\begin{tabular}{|c|c|c|}
\hline Labels & $\delta_{\mathrm{C}} / \delta_{\mathrm{H}}(\mathrm{ppm})$ & Assignment \\
\hline $\mathrm{B}_{\beta}$ & $53.5 / 3.07$ & $\mathrm{C}_{\beta}-\mathrm{H}_{\beta}$ in $\beta-\beta^{\prime}$ resinol substructures (B) \\
\hline $\mathrm{C}_{\beta}$ & $53.0 / 3.48$ & $\mathrm{C}_{\beta}-\mathrm{H}_{\beta}$ in phenylcoumaran substructures $(\mathrm{C})$ \\
\hline $\mathrm{MeO}$ & $55.6 / 3.72$ & $\mathrm{C}-\mathrm{H}$ in methoxyls \\
\hline $\mathrm{A}_{\gamma}$ & $59.9 / 3.40$ and 3.68 & $\mathrm{C}_{\gamma}-\mathrm{H}_{\gamma}$ in $\gamma$-hydroxylated $\beta-O-4^{\prime}$ substructures (A) \\
\hline $\mathrm{F}_{\gamma}$ & $61.2 / 4.08$ & $\mathrm{C}_{\gamma}-\mathrm{H}_{\gamma}$ in cinnamyl alcohol end-groups $(\mathrm{F})$ \\
\hline $\mathrm{C}_{\gamma}$ & $62.5 / 3.70$ & $\mathrm{C}_{\gamma}-\mathrm{H}_{\gamma}$ in phenylcoumaran substructures $(\mathrm{C})$ \\
\hline $\mathrm{B}_{\gamma}$ & $71.0 / 3.80$ and 4.15 & $\mathrm{C}_{\gamma}-\mathrm{H}_{\gamma}$ in $\beta-\beta^{\prime}$ resinol substructures (B) \\
\hline $\mathrm{A}_{\alpha}$ & $71.6 / 4.82$ & $\mathrm{C}_{\alpha}-\mathrm{H}_{\alpha}$ in $\beta-O-4^{\prime}$ substructures (A) \\
\hline $\mathrm{A}_{\alpha}^{\prime}$ & $80.0 / 4.50$ & $\begin{array}{l}\mathrm{C}_{\alpha}-\mathrm{H}_{\alpha} \text { in } \alpha \text {-methoxylated, ethoxylated, propoxyed and } \\
\text { butoxyed } \beta-O-4^{\prime} \text { substructures }\left(\mathrm{A}^{\prime}\right)\end{array}$ \\
\hline $\mathrm{A}_{\alpha}^{\prime}-\mathrm{OCH}_{3}$ & $56.5 / 3.18$ & The methyl in $\alpha$-methoxylated $\beta-O-4^{\prime}$ substructures $\left(\mathrm{A}^{\prime}\right)$ \\
\hline $\mathrm{A}_{\alpha}^{\prime}-\mathrm{OCH}_{2} \mathrm{CH}_{3}$ & $64.0 / 3.35$ & The methylene in $\alpha$-ethoxylated $\beta-O-4^{\prime}$ substructures $\left(\mathrm{A}^{\prime}\right)$ \\
\hline $\mathrm{A}_{\alpha}^{\prime}-\mathrm{OCH}_{2} \mathrm{CH}_{2} \mathrm{CH}_{3}$ & $70.0 / 3.22$ & the methylene in $\alpha$-propoxyed $\beta-O-4^{\prime}$ substructures $\left(\mathrm{A}^{\prime}\right)$ \\
\hline $\mathrm{A}_{\alpha}^{\prime}-\mathrm{OCH}_{2} \mathrm{CH}_{2} \mathrm{CH}_{2} \mathrm{CH}_{3}$ & $68.0 / 3.28$ & the methylene in $\alpha$-butoxyed $\beta-O-4^{\prime}$ substructures $\left(\mathrm{A}^{\prime}\right)$ \\
\hline $\mathrm{A}_{\beta}(\mathrm{G})$ & $84.0 / 4.28$ & $\mathrm{C}_{\beta}-\mathrm{H}_{\beta}$ in $\beta-O-4^{\prime}$ substructures (A) linked to a $\mathrm{G}$ unit \\
\hline $\mathrm{B}_{\alpha}$ & $84.8 / 4.62$ & $\mathrm{C}_{\alpha}-\mathrm{H}_{\alpha}$ in $\beta-\beta^{\prime}$ resinol substructures (B) \\
\hline$A_{\beta}(S)$ & $85.8 / 4.12$ & $\mathrm{C}_{\beta}-\mathrm{H}_{\beta}$ in $\beta-O-4^{\prime}$ substructures (A) linked to a $\mathrm{S}$ unit \\
\hline $\mathrm{C}_{\alpha}$ & $86.8 / 5.45$ & $\mathrm{C}_{\alpha}-\mathrm{H}_{\alpha}$ in phenylcoumaran substructures $(\mathrm{C})$ \\
\hline$S_{2,6}$ & $103.8 / 6.62$ & $\mathrm{C}_{2,6}-\mathrm{H}_{2,6}$ in etherified syringyl units (S) \\
\hline$S_{2,6}^{\prime}$ & $106.5 / 7.18$ & $\mathrm{C}_{2,6}-\mathrm{H}_{2,6}$ in oxidized syringyl units $\left(\mathrm{S}^{\prime}\right)$ \\
\hline $\mathrm{G}_{2}$ & $111.0 / 6.95$ & $\mathrm{C}_{2}-\mathrm{H}_{2}$ in guaiacyl units $(\mathrm{G})$ \\
\hline $\mathrm{G}_{5}$ & $115.0 / 6.72$ & $\mathrm{C}_{5}-\mathrm{H}_{5}$ in guaiacyl units $(\mathrm{G})$ \\
\hline $\mathrm{G}_{6}$ & $118.8 / 6.72$ & $\mathrm{C}_{6}-\mathrm{H}_{6}$ in guaiacyl units $(\mathrm{G})$ \\
\hline $\mathrm{I}_{2}$ & 109.5/7.10 & $\mathrm{C}_{2}-\mathrm{H}_{2}$ in stilbenes units $(\mathrm{I})$ \\
\hline $\mathrm{I}_{\alpha / \beta}$ & $126.0 / 6.98$ & $\mathrm{C}_{\alpha / \beta}-\mathrm{H}_{\alpha / \beta}$ in stilbenes units (I) \\
\hline $\mathrm{F}_{\alpha / \beta}$ & 122.0/7.05 & $\mathrm{C}_{\alpha / \beta}-\mathrm{H}_{\alpha / \beta}$ in cinnamyl alcohol end-groups $(\mathrm{F})$ \\
\hline $\mathrm{PB}_{2,6}$ & $129.8 / 7.50$ & $\mathrm{C}_{2,6}-\mathrm{H}_{2,6}$ in $p$-hydroxybenzoate substructures (PB) \\
\hline
\end{tabular}

TABLE 3: Structural characteristics (lignin interunit linkages and $S / G$ ratio) from integration of ${ }^{13} \mathrm{C}-{ }^{1} \mathrm{H}$ correlation peaks in the HSQC spectra of the lignin fractions from hybrid poplar.

\begin{tabular}{lcccc}
\hline Linkage relative abundance $(\%)$ & MOL & EOL & POL & BOL \\
\hline$\beta$-Aryl-ether units $\left(\beta-O-4^{\prime}, \mathrm{A}\right)$ & 60.7 & 70.6 & 66.7 & 65.4 \\
Resinols substructures $\left(\beta-\beta^{\prime}, \mathrm{B}\right)$ & 31.7 & 24.0 & 28.3 & 27.7 \\
Phenylcoumarans substructures $\left(\beta-5^{\prime}, \mathrm{C}\right)$ & 7.6 & 5.4 & 5.0 & 6.9 \\
$S / G$ ratio & 3.09 & 3.46 & 2.54 & 2.76 \\
\hline
\end{tabular}

occurred between 200 and $450^{\circ} \mathrm{C}$ and the maximum rates of MOL, EOL, POL, and BOL were 39.75, 41.42, 37.01, and $34.16 \%$, respectively. The weight losses in this stage were speculated to be mainly owing to ether linkages, side chain oxidation (i.e., carbonylation/carboxylation of aliphatic hydroxyl group, side chain dehydrogenation), and partial C$\mathrm{C}$ bond (5-5) cleavages within lignin biopolymers [41]. In the last stage (temperature over $450^{\circ} \mathrm{C}$ ), further decomposition and recondensation of aromatic rings occurred and simultaneously the cracking of the methoxyl $\left(\mathrm{OCH}_{3}\right)$ groups and methane release also happened around $400-600^{\circ} \mathrm{C}[18,39]$. It was found that the char residues at $600^{\circ} \mathrm{C}$ were $39.75 \%$, $41.42 \%, 37.01 \%$, and $34.16 \%$ from MOL, EOL, POL, and BOL, respectively. In addition, thermal stability of the four lignin fractions could represent the highest degradation temperatures in curves of DTG, which were observed to be 374.4 , $376.8,370.4$, and $372.8^{\circ} \mathrm{C}$ for $\mathrm{MOL}, \mathrm{EOL}, \mathrm{POL}$, and $\mathrm{BOL}$, respectively.

\section{Conclusions}

The effect of autocatalyzed organosolv pretreatment on fractionation of lignin biopolymer and its structural changes was comparatively investigated. It was found that the yield of lignin extracted with ethanol was the highest as compared with that from other solvents including methanol, 1-propanol, 
<smiles>COc1cc(C)cc(C)c1OC(CO)C(O)c1cc(OC)c(OC)c(OC)c1</smiles>

A<smiles>COc1cc(OC)c2c(c1)C(CO)C(c1ccc(OC)c(OC)c1)O2</smiles>

C<smiles>COc1ccc(C(C)O)cc1OCCO</smiles>

G<smiles>[R6]C(/C(=C/O)Oc1c(C)cc(C)cc1OC)c1cc(OC)c(OC)c(OC)c1</smiles>

$\mathrm{A}^{\prime}$<smiles>COc1cc(C=CCO)cc(C)c1OC</smiles>

$\mathrm{F}$

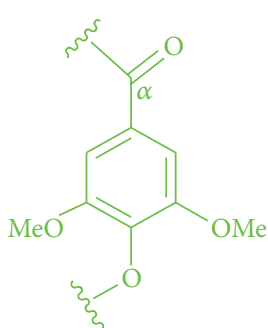

$S^{\prime}$<smiles>CCOc1c(C)cc(C2[Te]OC3(C)C(c4cc(C)c(OCC)c(OC)c4)OCC23C)cc1OC</smiles><smiles>CCOc1c(C)cc(C=Cc2cc(C)c(O)c(OC)c2)cc1OC</smiles><smiles>CCOC(=O)c1ccc(O)cc1</smiles>

PB

Figure 6: Main substructures present in the alcohol lignin of hybrid poplar: (A) $\beta$-O- $4^{\prime}$ alkyl-aryl ethers; $\left(\mathrm{A}^{\prime}\right) \mathrm{C} \alpha$-substituted $\beta$ - $O$ - $4^{\prime}$ structures $\left(\mathrm{R}=\mathrm{CH}_{3}, \mathrm{CH}_{2} \mathrm{CH}_{3}, \mathrm{CH}_{2} \mathrm{CH}_{2} \mathrm{CH}_{3}, \mathrm{CH}_{2} \mathrm{CH}_{2} \mathrm{CH}_{2} \mathrm{CH}_{3}\right)$; (B) resinol; (C) phenylcoumaran; (F) cinnamyl alcohol end-group; (I) stilbenes; (PB) p-hydroxybenzoate; $(\mathrm{G})$ guaiacyl units; $(\mathrm{S})$ syringyl units; $\left(\mathrm{S}^{\prime}\right)$ oxidized syringyl units.

and 1-butanol. As seen from results of sugar analysis, the lignin fractions extracted from methanol, ethanol, and 1propanol were composed of small quantity of neutral sugars (1.16-1.46\%) apart from lignin preparation obtained from 1butanol (7.53\%). Moreover, the analysis of 2D NMR spectra indicated that the lignin fractions mainly consisted of syringyl units with noticeable amounts of guaiacyl units. In addition, the interlinkages including $\beta-O-4^{\prime}$ linkages as well as fewer $\beta-\beta^{\prime}$ and $\beta-5^{\prime}$ linkages were observed. It was also noted that the substitutions of $C_{\alpha}$ in $\beta-O-4^{\prime}$ substructures existed in all the autocatalyzed alcohol organosolv pretreatments. In comparison, ethanol was found to be the most promising alcoholic organic solvent for the pretreatment of lignocellulosic biomass in biorefinery.

\section{Conflict of Interests}

The authors declare that there is no conflict of interests regarding the publication of this paper. 


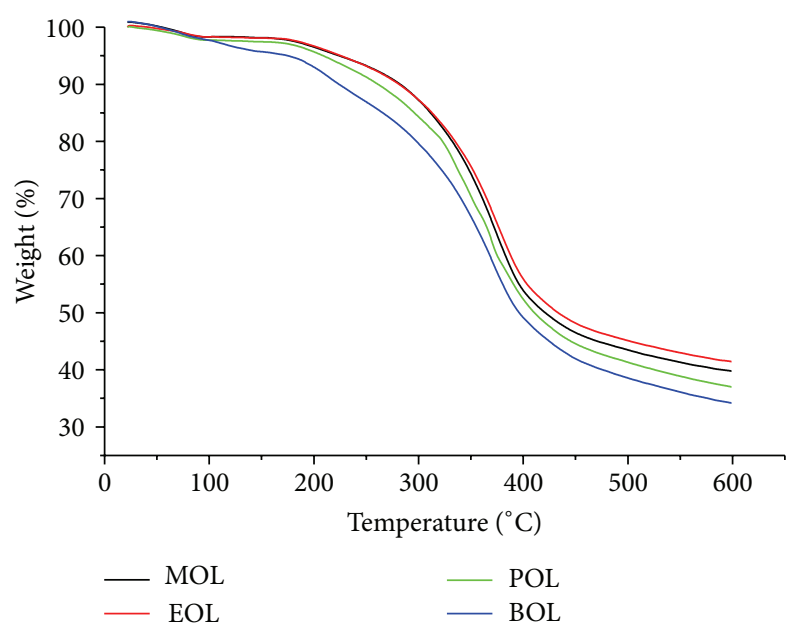

FIGURE 7: TGA distributions of the isolated alcohol lignin fractions from hybrid poplar.

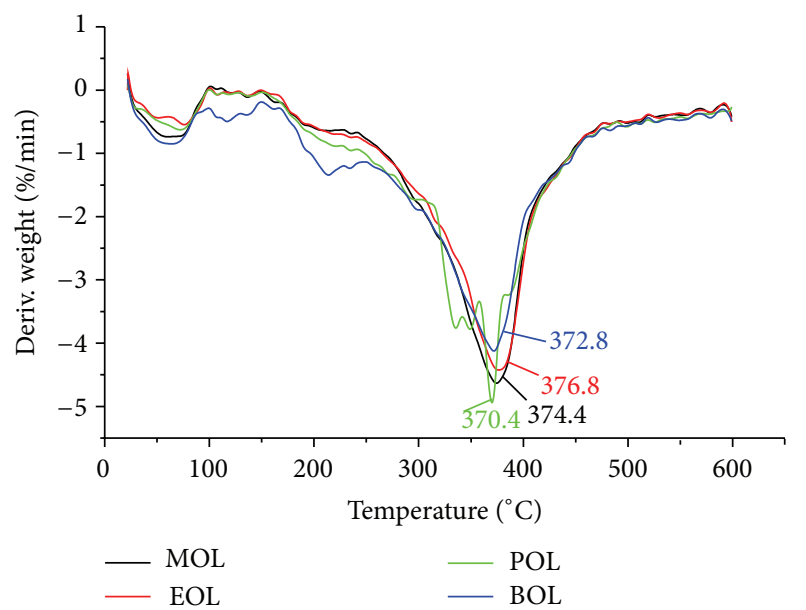

FIGURE 8: DTG distributions of the isolated alcohol lignin fractions from hybrid poplar.

\section{Acknowledgments}

The authors are grateful for the financial support of this research from the Beijing Higher Education Young Elite Teacher Project (YETP0766), Program for New Century Excellent Talents in University (NCET-12-0782), and the Natural Science Foundation of China (no. 31170557).

\section{References}

[1] Y. Li and A. J. Ragauskas, "Ethanol organosolv lignin-based rigid polyurethane foam reinforced with cellulose nanowhiskers," RSC Advances, vol. 2, no. 8, pp. 3347-3351, 2012.

[2] S.-N. Sun, M.-F. Li, T.-Q. Yuan, F. Xu, and R.-C. Sun, "Sequential extractions and structural characterization of lignin with ethanol and alkali from bamboo (Neosinocalamus affinis)," Industrial Crops and Products, vol. 37, no. 1, pp. 51-60, 2012.

[3] J. Yamazaki, E. Minami, and S. Saka, "Liquefaction of beech wood in various supercritical alcohols," Journal of Wood Science, vol. 52, no. 6, pp. 527-532, 2006.

[4] F. M. Gírio, C. Fonseca, F. Carvalheiro, L. C. Duarte, S. Marques, and R. Bogel-Łukasik, "Hemicelluloses for fuel ethanol: a review," Bioresource Technology, vol. 101, no. 13, pp. 4775-4800, 2010.

[5] B. B. Hallac, Y. Pu, and A. J. Ragauskas, "Chemical transformations of Buddleja davidii lignin during ethanol organosolv pretreatment," Energy \& Fuels, vol. 24, no. 4, pp. 2723-2732, 2010.

[6] A. Romaní, G. Garrote, F. López, and J. C. Parajó, "Eucalyptus globulus wood fractionation by autohydrolysis and organosolv delignification," Bioresource Technology, vol. 102, no. 10, pp. 5896-5904, 2011.

[7] N. Mosier, C. Wyman, B. Dale et al., "Features of promising technologies for pretreatment of lignocellulosic biomass," Bioresource Technology, vol. 96, no. 6, pp. 673-686, 2005.

[8] K. Wörmeyer, T. Ingram, B. Saake, G. Brunner, and I. Smirnova, "Comparison of different pretreatment methods for lignocellulosic materials. Part II: influence of pretreatment on the properties of rye straw lignin," Bioresource Technology, vol. 102, no. 5, pp. 4157-4164, 2011.

[9] E. K. Pye and J. H. Lora, "The Alcell process a proven alternative to kraft pulping," TAPPI Journal, vol. 74, no. 3, pp. 113-118, 1991.

[10] J. H. Clark, F. E. I. Deswarte, and T. J. Farmer, "The integration of green chemistry into future biorefineries," Biofuels, Bioproducts and Biorefining, vol. 3, no. 1, pp. 72-90, 2009.

[11] R. E. Hage, N. Brosse, L. Chrusciel, C. Sanchez, P. Sannigrahi, and A. Ragauskas, "Characterization of milled wood lignin and ethanol organosolv lignin from miscanthus," Polymer Degradation and Stability, vol. 94, no. 10, pp. 1632-1638, 2009.

[12] D. Stewart, "Lignin as a base material for materials applications: chemistry, application and economics," Industrial Crops and Products, vol. 27, no. 2, pp. 202-207, 2008.

[13] C. Felby, L. G. Thygesen, A. Sanadi, and S. Barsberg, "Native lignin for bonding of fiber boards-evaluation of bonding mechanisms in boards made from laccase-treated fibers of beech (Fagus sylvatica)," Industrial Crops and Products, vol. 20, no. 2, pp. 181-189, 2004.

[14] M. Yáñez-S, J. Rojas, J. Castro, A. Ragauskas, J. Baeza, and J. Freer, "Fuel ethanol production from Eucalyptus globulus wood by autocatalized organosolv pretreatment ethanol-water and SSF," Journal of Chemical Technology and Biotechnology, vol. 88, no. 1, pp. 39-48, 2013.

[15] X. Pan, C. Arato, N. Gilkes et al., "Biorefining of softwoods using ethanol organosolv pulping: preliminary evaluation of process streams for manufacture of fuel-grade ethanol and coproducts," Biotechnology and Bioengineering, vol. 90, no. 4, pp. 473-481, 2005.

[16] X. Pan, N. Gilkes, J. Kadla et al., "Bioconversion of hybrid poplar to ethanol and co-products using an organosolv fractionation process: optimization of process yields," Biotechnology and Bioengineering, vol. 94, no. 5, pp. 851-861, 2006.

[17] N. Brosse, P. Sannigrahi, and A. Ragauskas, "Pretreatment of miscanthus $\mathrm{x}$ giganteus using the ethanol organosolv process for ethanol production," Industrial and Engineering Chemistry Research, vol. 48, no. 18, pp. 8328-8334, 2009.

[18] J.-L. Wen, B.-L. Xue, S.-L. Sun, and R.-C. Sun, "Quantitative structural characterization and thermal properties of birch lignins after auto-catalyzed organosolv pretreatment and enzymatic hydrolysis," Journal of Chemical Technology and Biotechnology, vol. 88, no. 9, pp. 1663-1671, 2013. 
[19] J. Wildschut, A. T. Smit, J. H. Reith, and W. J. J. Huijgen, "Ethanol-based organosolv fractionation of wheat straw for the production of lignin and enzymatically digestible cellulose," Bioresource Technology, vol. 135, pp. 58-66, 2013.

[20] A. L. Macfarlane, Organosolv delignification of willow: kinetics, recovery and use [Ph.D. thesis], The University of Auckland, Auckland, Australia, 2009.

[21] D.-E. Kim and X. Pan, "Preliminary study on converting hybrid poplar to high-value chemicals and lignin using organosolv ethanol process," Industrial and Engineering Chemistry Research, vol. 49, no. 23, pp. 12156-12163, 2010.

[22] X. Pan, D. Xie, R. W. Yu, D. Lam, and J. N. Saddler, "Pretreatment of lodgepole pine killed by mountain pine beetle using the ethanol organosolv process: fractionation and process optimization," Industrial and Engineering Chemistry Research, vol. 46, no. 8, pp. 2609-2617, 2007.

[23] L. F. Del Rio, R. P. Chandra, and J. N. Saddler, "Fibre size does not appear to influence the ease of enzymatic hydrolysis of organosolv-pretreated softwoods," Bioresource Technology, vol. 107, pp. 235-242, 2012.

[24] H. L. Chum, S. K. Black, D. K. Johnson, K. V. Sarkanen, and D. Robert, "Organosolv pretreatment for enzymatic hydrolysis of poplars: isolation and quantitative structural studies of lignins," Clean Products and Processes, vol. 1, no. 3, pp. 187-198, 1999.

[25] T. Kishimoto, A. Ueki, and Y. Sano, "Delignification mechanism during high-boiling solvent pulping: part 3. structural changes in lignin analyzed by ${ }^{13} \mathrm{C}-\mathrm{NMR}$ spectroscopy," Holzforschung, vol. 57, no. 6, pp. 602-610, 2003.

[26] T. Kishimoto, A. Ueki, H. Takamori, Y. Uraki, and M. Ubukata, "Delignification mechanism during high-boiling solvent pulping. Part 6: changes in lignin structure analyzed by ${ }^{1} \mathrm{H}-{ }^{13} \mathrm{C}$ correlation 2-D NMR spectroscopy," Holzforschung, vol. 58, no. 4, pp. 355-362, 2004.

[27] S. Kang, L. Xiao, L. Meng, X. Zhang, and R. Sun, "Isolation and structural characterization of lignin from cotton stalk treated in an ammonia hydrothermal system," International Journal of Molecular Sciences, vol. 13, no. 11, pp. 15209-15226, 2012.

[28] A. Sluiter, B. Hames, R. Ruiz et al., Determination of Structural Carbohydrates and Lignin in Biomass, Laboratory Analytical Procedure, 2008.

[29] O. Faix, "Classification of lignins from different botanical origins by FT-I R spectroscopy," Holzforschung, vol. 45, no. 1, pp. 21-28, 1991.

[30] S. Bauer, H. Sorek, V. D. Mitchell, A. B. Ibáñez, and D. E. Wemmer, "Characterization of Miscanthus giganteus lignin isolated by ethanol organosolv process under reflux condition," Journal of Agricultural and Food Chemistry, vol. 60, no. 33, pp. 82038212, 2012.

[31] A. V. Marques, H. Pereira, J. Rodrigues, D. Meier, and O. Faix, "Isolation and comparative characterization of a Björkman lignin from the saponified cork of Douglas-fir bark," Journal of Analytical and Applied Pyrolysis, vol. 77, no. 2, pp. 169-176, 2006.

[32] J. Rencoret, G. Marques, A. Gutiérrez et al., "Structural characterization of milled wood lignins from different eucalypt species," Holzforschung, vol. 62, no. 5, pp. 514-526, 2008.

[33] J. Rencoret, G. Marques, A. Gutiérrez et al., "Isolation and structural characterization of the milled-wood lignin from Paulownia fortunei wood," Industrial Crops and Products, vol. 30, no. 1, pp. 137-143, 2009.

[34] L. P. Xiao, Z. J. Shi, F. Xu, and R. C. Sun, "Characterization of MWLs from Tamarix ramosissima isolated before and after hydrothermal treatment by spectroscopical and wet chemical methods," Holzforschung, vol. 66, no. 3, pp. 295-302, 2012.

[35] L. Y. Meng, S. M. Kang, X. M. Zhang, Y. Y. Wu, and R.-C. Sun, "Isolation and physico-chemical characterization of lignin from hybrid poplar in dmso/licl system induced by microwaveassisted irradiation," Cellulose Chemistry and Technology, vol. 46, no. 5-6, pp. 409-418, 2012.

[36] R. El Hage, N. Brosse, P. Sannigrahi, and A. Ragauskas, "Effects of process severity on the chemical structure of Miscanthus ethanol organosolv lignin," Polymer Degradation and Stability, vol. 95, no. 6, pp. 997-1003, 2010.

[37] R. Samuel, M. Foston, N. Jaing et al., "HSQC (heteronuclear single quantum coherence $)^{13} \mathrm{C}-{ }^{1} \mathrm{H}$ correlation spectra of whole biomass in perdeuterated pyridinium chloride-DMSO system: an effective tool for evaluating pretreatment," Fuel, vol. 90, no. 9, pp. 2836-2842, 2011.

[38] J. L. Wen, S. L. Sun, B. L. Xue, and R. C. Sun, "Recent advances in characterization of lignin polymer by solution-state nuclear magnetic resonance (NMR) methodology," Materials, vol. 6, no. 1, pp. 359-391, 2013.

[39] M.-F. Li, S.-N. Sun, F. Xu, and R.-C. Sun, "Formic acid based organosolv pulping of bamboo (Phyllostachys acuta): comparative characterization of the dissolved lignins with milled wood lignin," Chemical Engineering Journal, vol. 179, pp. 80-89, 2012.

[40] M.-F. Li, S.-N. Sun, F. Xu, and R.-C. Sun, "Sequential solvent fractionation of heterogeneous bamboo organosolv lignin for value-added application," Separation and Purification Technology, vol. 101, pp. 18-25, 2012.

[41] H. Yang, R. Yan, H. Chen, D. H. Lee, and C. Zheng, "Characteristics of hemicellulose, cellulose and lignin pyrolysis," Fuel, vol. 86, no. 12-13, pp. 1781-1788, 2007. 

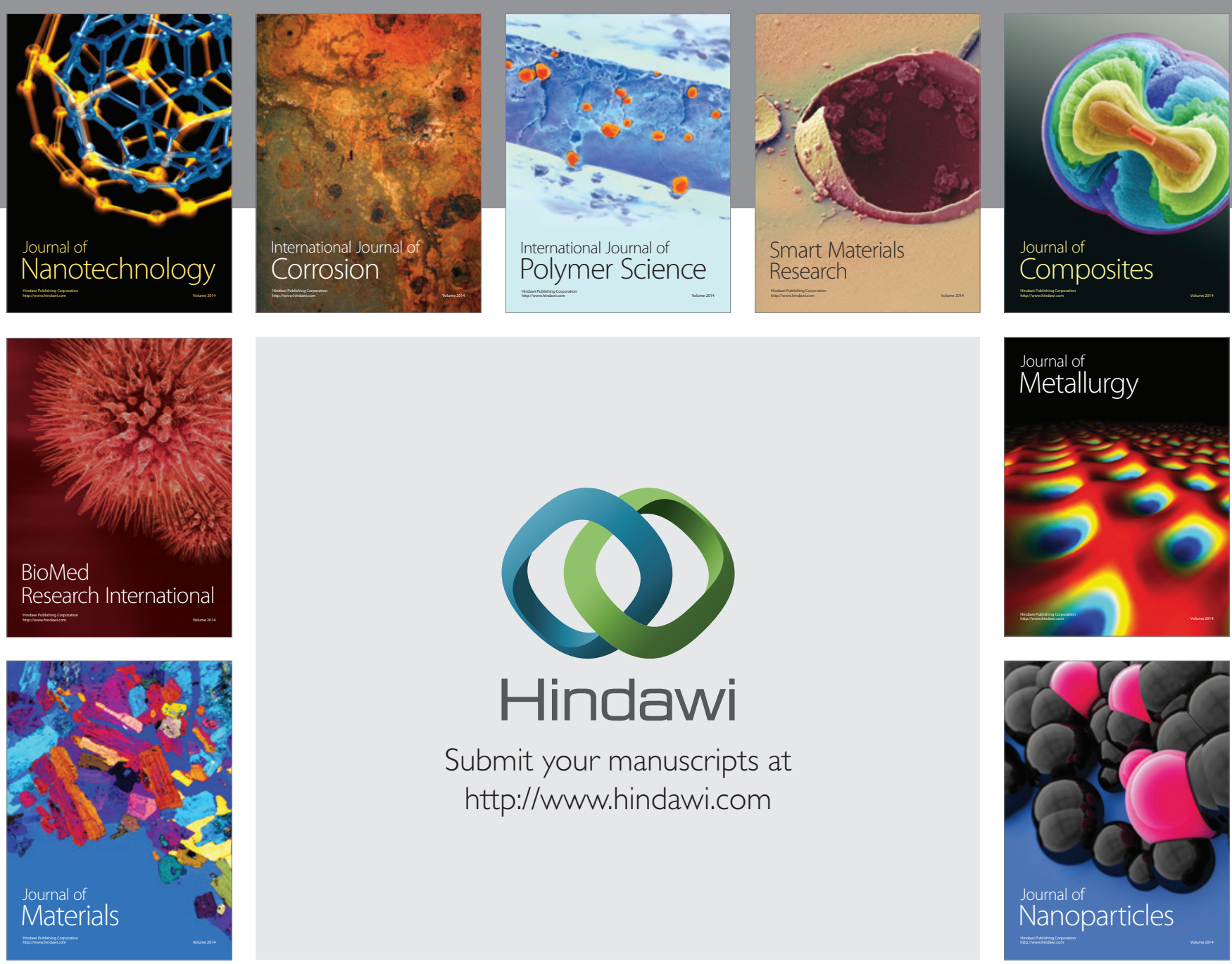

Submit your manuscripts at http://www.hindawi.com
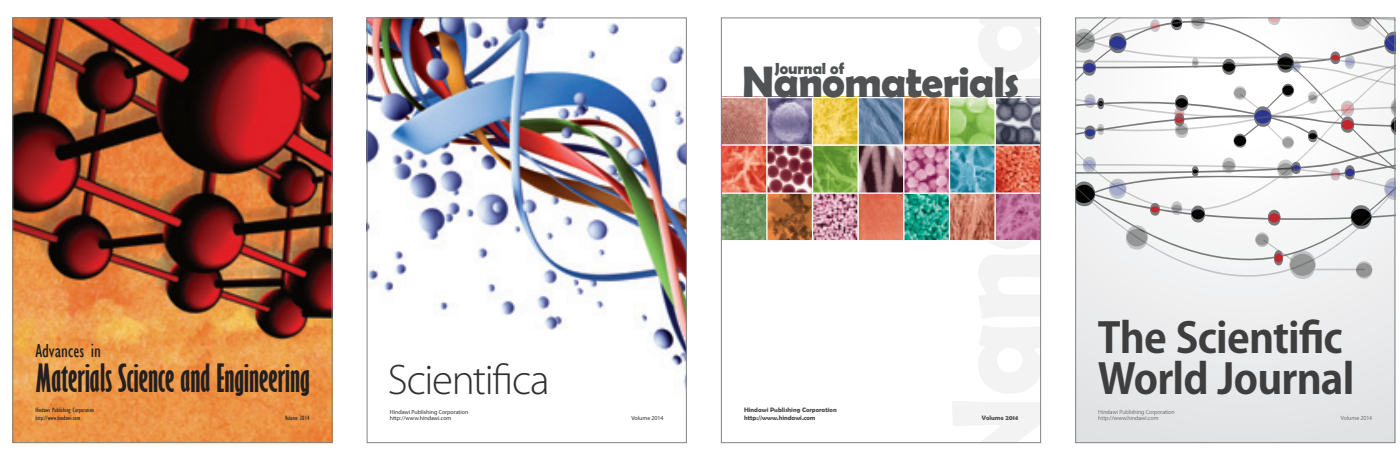

\section{The Scientific World Journal}
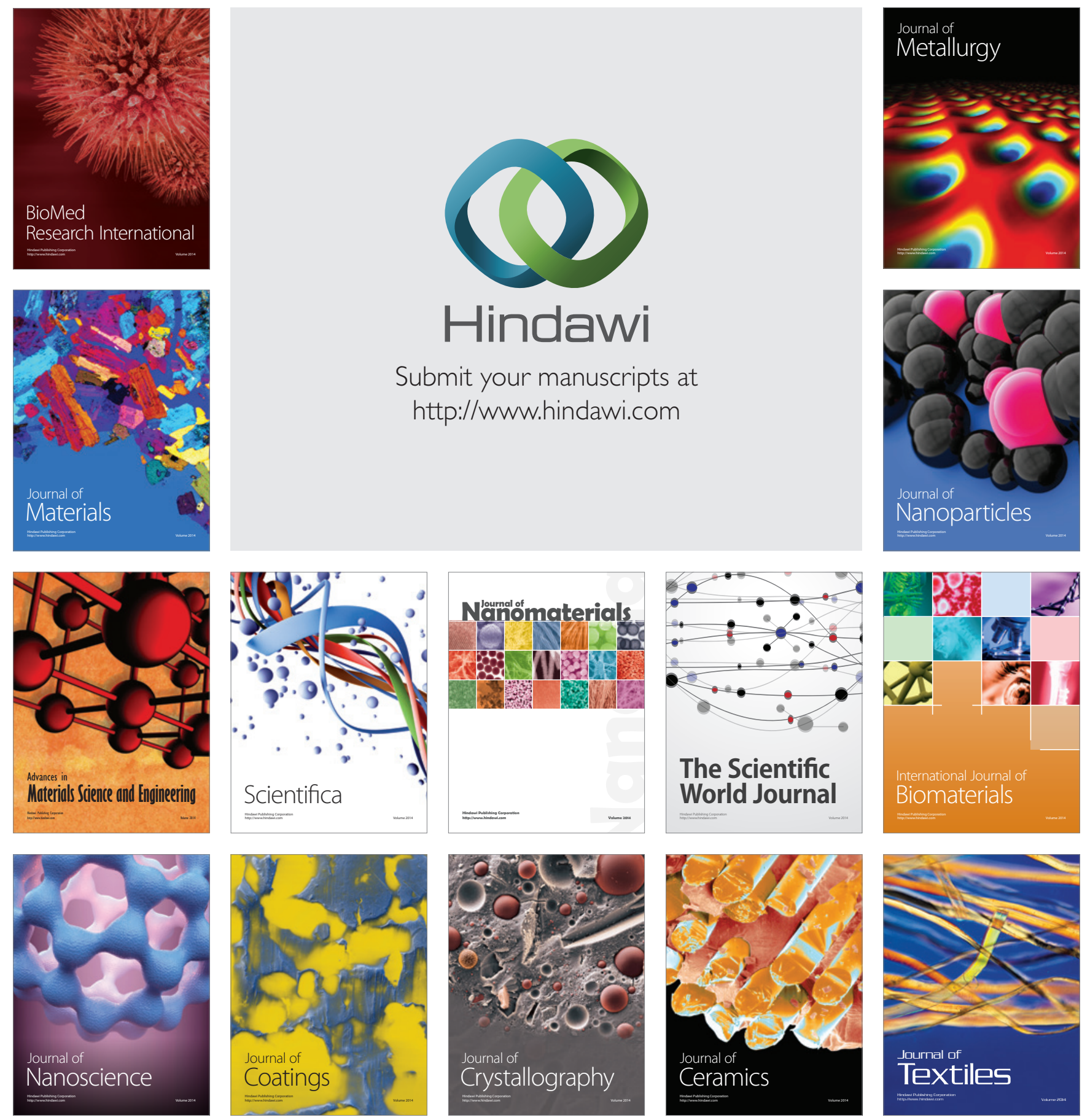